\title{
The Effect of Giving Fish Cork Albumin Gel (Channa Striata) to the Mice Wound Closure
}

\author{
Dimareta Puspitasari*, Eddy Suprayitno** \\ *Department of Fisheries Technology \\ Faculty of Fisheries and marine science \\ Brawijaya university Indonesia \\ dimaretapuspita@student.ub.ac.id \\ **Department of Fisheries Technology \\ Faculty of Fisheries and marine science \\ Brawijaya university Indonesia \\ eddysuprayitno@ub.ac.id \\ DOI: 10.29322/IJSRP.10.07.2020.p10360 \\ http://dx.doi.org/10.29322/IJSRP.10.07.2020.p10360
}

\begin{abstract}
Gel is a semisolid or thick preparation, which is made by mixing an extract (active substance) with a suitable base. During this time cork fish albumin consumed in the form of extract or powder. Cork fish albumin is consumed orally, many do not like it because of the pungent odor and easy stale. So that new innovations are needed to develop albumin products into albumin gels that can be applied with a rub to the skin. The gel has the advantage of not being sticky, easily applied, easy to wash and does not leave an oily coating on the skin thereby reducing the risk of further inflammation. The results of Phase 1 research showed that differences in the concentration of cork fish albumin extract affected the quality of albumin gel, namely $\mathrm{pH}$, viscosity, albumin content, protein content, fat content, water content. The best albumin gel was obtained at $6 \%$ cork fish albumin extract concentration with the following results: $\mathrm{pH} 7$, viscosity $3594 \mathrm{cP}$, albumin content $2.00 \%$, protein content $3.18 \%$, fat content $2.72 \%$, and water content 93.31\%. Amino acid profile test results obtained the highest results of L-serine $830.17 \mathrm{mg} / \mathrm{kg}$ and the lowest L-valine $155.64 \mathrm{mg} /$ $\mathrm{kg}$. Then proceed to Phase 2 of the study namely amino acid profile test, zinc levels and animal mice obtained observations on day 3 , day 5 , and day 7 showed the best $6 \%$ albumin concentration gel treatment had a wound closure process. wound character closed $80 \%$ on the 7th day.
\end{abstract}

Index Terms- gel, albumin, wound closure, amino acid profile

\section{INTRODUCTION}

Cork fish has albumin levels to speed up the process of healing internal or external wounds. Albumin is a globular protein that is often used for nutrition improvement and postoperative wound recovery. This album works on osmotic pressure in the blood (Firlianty and Pratasik, 2018). In addition to albumin, the wound cover on several components, namely the role of collagen, omega 3 fatty acids and omega 6 (Nicodemus et al., 2014). Collagen is a key component in the phase of wound closure. The collagen characteristics that attach cells to form new connected tissues (Siregar and Suprayitno, 2019). The collagen used is collagen from grouper skin because grouper has the best collagen content (Suprayitno, 2019). Omega-3 and omega-6 fatty acids are PUFAs (Double Unsaturated Fatty Acids). Arachidonic acid is a derivative of omega-6. Omega-3 fatty acids are available in the form of DHA and EPA. Omega-3 and omega- 6 fatty acids play an important role in the process of wound healing (Nicodemus et al., 2014). Source of omega 3 fatty acids from soybean oil and omega 6 fatty acids from sunflower oil.

Cork fish albumin has been consumed in extract or powder form. Albumin extract is consumed orally. Weakness of cork fish extract, among others, many people who do not like albumin extract because the pungent odor causes nausea when consumed and is easily stale. The solution to overcome the adverse effects of albumin extract is that albumin extract is developed into a gel that can be applied directly to the skin of patients (Tungadi, et al., 2018). Gel is a semisolid, which is made by mixing the extract as an active ingredient. Gel has the advantage of being non-sticky, easily applied, easily washed and does not cause irritation. This research was used to develop albumin extract with the addition of collagen, fatty acids from essential oils containing omega 3 and omega 6 into cream gel so that people more easily apply it to cuts..

\section{MATERIALS AND METHODS}

\subsection{Material}


The research material used consisted of raw materials for the production of albumin extract, namely cork fish, materials for making collagen is grouper skin, $\mathrm{NaOH}$, astic acid and aquades. Materials for making albumin gel are albumin extracts derived from cork fish extract, collagen, sunflower oil as a source of omega 6, soybean oil as a source of omega 3 and fillers using HPMC (Hydroxypropyl Methylcellulose). propylene glycol (PG), metal parabens, propyl parabens, triethanolamine (TEA), aquades. Formulations for making albumin can be seen in the following table.

\begin{tabular}{lrrr}
\hline & \multicolumn{3}{c}{ Concentration $(\%)$} \\
\hline Extract albumin & $3 \%$ & $4.5 \%$ & $6 \%$ \\
Collagen & 3 & 4.5 & 6 \\
Sunflower oil & 0.6 & 0.6 & 0.6 \\
Soybean oil & 3 & 3 & 3 \\
HPMC & 2.4 & 2.4 & 2.4 \\
Triethanolamine & 3 & 3 & 3 \\
Propylene glycol & 2 & 2 & 2 \\
Methyl paraben & 5 & 5 & 5 \\
Propyl parabens & 0.18 & 0.18 & 0.18 \\
Ad Aquades & 0.2 & 0.2 & 0.2 \\
\hline
\end{tabular}

This research method is an experimental method. In this research, 2 stages were carried out. Stage 1 and stage 2 research. Stage 1 aims to obtain what is the optimal concentration of cork fish albumin extract added to the making of albumin gel so that the best gel quality is obtained for stage 2 research. While the stage 2 study aims to look at the process of wound closure in experimental animals using gel the highest quality albumin compared to negative control and negative control.

\subsubsection{Making Albumin Extract}

The making of albumin extract begins with the preparation of raw materials ie cork fish is turned off, then weeded, filleting, diced and washed. Furthermore, cork fish weighed 250 grams, then put into steam at a temperature of $70^{\circ} \mathrm{C}$. Cork fish meat steamed for 30 minutes. After that filtered and taken filtrate. Cork fish extract is ready to use.

\subsubsection{Making the Collagen}

The first collagen production is done by preparing grouper skin that has been removed from the scales. Then grouper skin is cut $1 \times 1 \mathrm{~cm}$. Furthermore, the skin of grouper soaked in $0.1 \mathrm{M} \mathrm{NaOH}$ for 24 hours with a ratio of skin and solution of 1:10. After that the grouper skin is neutralized with aquades. Furthermore, soaked with acetic acid in the ratio of 1:10 for 24 hours. Then filtered and taken the filtrate. After that, precipitation was done with $\mathrm{NaCl} 0.9 \mathrm{M}$ for 24 hours. Then centrifuged at a speed of 3500 rpm for 20 minutes. Further dialysis with $0.5 \mathrm{M}$ acetic acid with a ratio of 1:10. After that it is inserted into the cellophane membrane. Then immersed in $0.1 \mathrm{M}$ acetic acid solution for 6 hours. Furthermore, soaked with aquades to neutral pH. After that, collagen is ready to use.

\subsubsection{Making Gel Albumin}

Preparation of albumin gel begins with HPMC dissolved in aquades and then TEA is added. Methyl paraben and propyl paraben are dissolved in propylene glycol, then albumin extract is added with concentrations of 3\%, 4.5\%, and 6\%, then respectively grouper skin collagen, soybean oil, and sunflower oil are added. After that all the ingredients are mixed and added to 100 ml of aquades. Albumin gel analyzed physics ( $\mathrm{pH}$ and viscosity), albumin levels, chemistry (protein, fat, and water), and organoleptics.

\section{RESULT AND DISCUSSION}

\section{$3.1 \mathrm{pH}$}

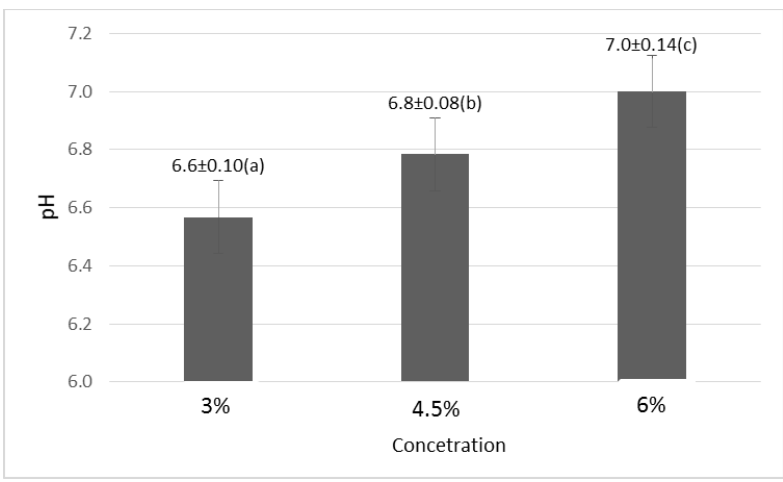

This publication is licensed under Creative Commons Attribution CC BY.

http://dx.doi.org/10.29322/IJSRP.10.07.2020.p10360

WWW.ijsrp.org 
Figure 1. The Result of $\mathrm{pH}$

The $\mathrm{pH}$ of albumin gel with different concentrations of albumin extract results in different $\mathrm{pH}$ values. At $3 \%$ albumin extract concentration produced a $\mathrm{pH}$ value of 6.6 , a $4.5 \%$ concentration of 6.8 , and a $6 \%$ albumin extract concentration obtained $\mathrm{pH} 7$. The highest $\mathrm{pH}$ value was obtained from the highest albumin extract concentration of $6 \%$ with a $\mathrm{pH}$ value of 7 , and the lowest was obtained at a concentration the lowest cork fish albumin extract was 3\% at 6.6. The $\mathrm{pH}$ value of albumin gel produced is still within the $\mathrm{pH}$ range that is safe for the skin that is 5.8-7.2 (Vashist, et al., 2015), so that the albumin gel does not irritate the skin or make the skin dry.

\subsection{Viscosity}

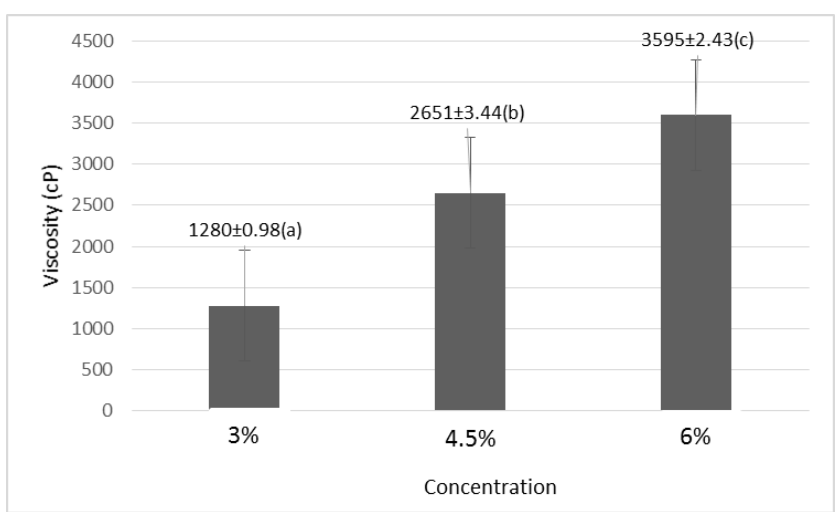

Figure 2. The Result of Viscosity

Viscosity value at $3 \%$ albumin extract concentration of $1280 \mathrm{cP}, 4.5 \%$ concentration obtained viscosity value of $2651 \mathrm{cP}$, and at $6 \%$ concentration of $3595 \mathrm{cP}$. The results of the viscosity of the gel which has the highest value is albumin gel with a concentration of $6 \%$ albumin extract of $3595 \mathrm{cP}$, and the lowest results obtained at a concentration of $3 \%$ of $1280 \%$. The viscosity range for good gels is 2000-4000 cP (Husnani and Muazham, 2017).

\subsection{Albumin Content}

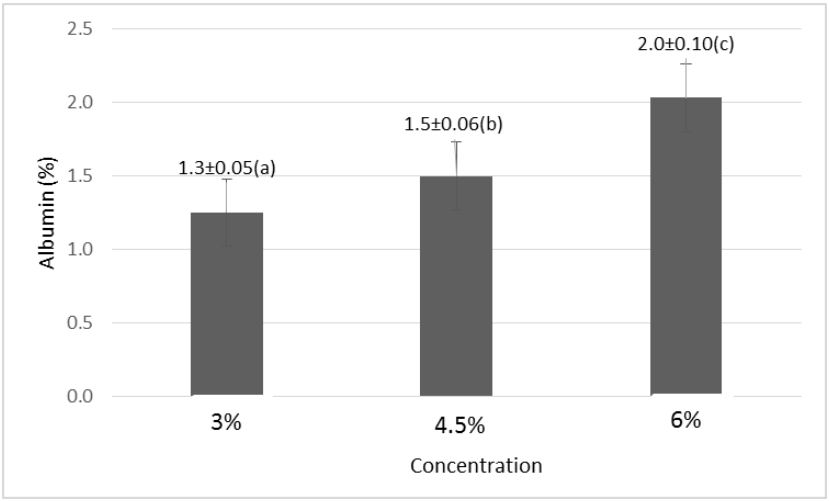

Figure 3. The Result of Albumin Content

Albumin concentration at 3\% albumin extract concentration was $1.3 \%, 4.5 \%$ concentration was $1.5 \%$, and albumin concentration of $6 \%$ cork fish albumin extract was $2.0 \%$. The highest albumin content was shown at a concentration of $6 \%$, which was $2.0 \%$, while the lowest albumin level was at a concentration of $3 \%$ at $1.3 \%$. The albumin content in the resulting albumin gel showed an increase along with the increasing concentration of the albumin extract given.

\subsection{Protein Content}




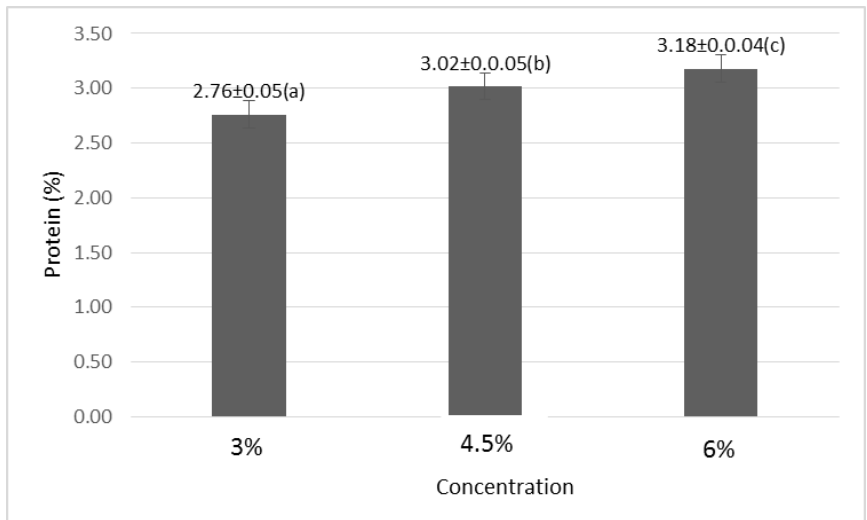

Figure 4. The Result of Protein Content

The protein content of albumin gel at cork fish extract albumin concentration of $3 \%$ was $2.76 \%$, the concentration of $4.5 \%$ was $3.02 \%$, and the concentration of $6 \%$ had a protein content of 3.18\%. the highest protein content obtained $6 \%$ concentration of $3.18 \%$ and the lowest concentration of $3 \%$ of $2.76 \%$. It can be concluded that the higher the concentration of albumin extract, the greater the protein content produced. Albumin is part of the protein, so if the cork fish albumin extract increases so does the protein content.

\subsection{Fat Content}

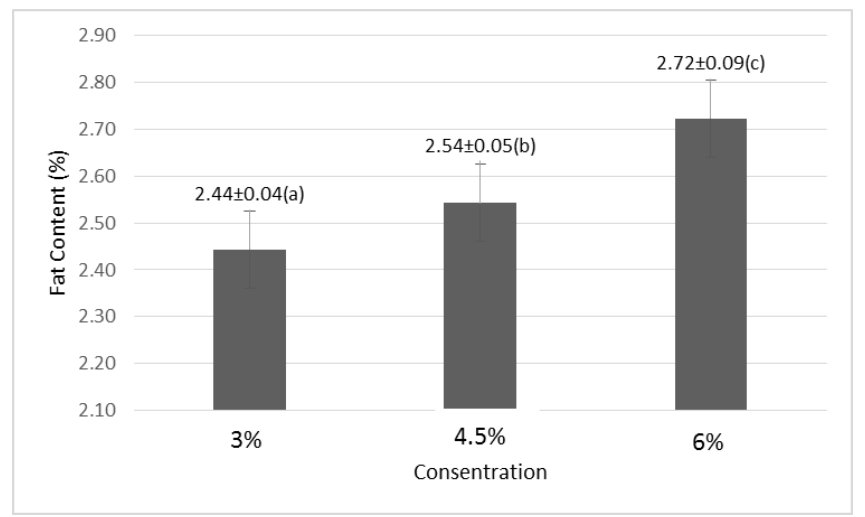

Figure 5. The Result of Fat Content

Fat content in cork fish extract albumin concentration of $3 \%$ was $2.44 \%, 4.5 \%$ concentration was $2.54 \%$, and fat content at $6 \%$ concentration was $2.72 \%$. the highest fat content was found in albumin gel concentration of $6 \%$ by $2.72 \%$, while the lowest concentration of 3\% was $2.44 \%$. Fat content contained in albumin gel comes from omega 3 source oil, omega 6 source oil added and fat content in the fish cork.

\subsection{Water Content}

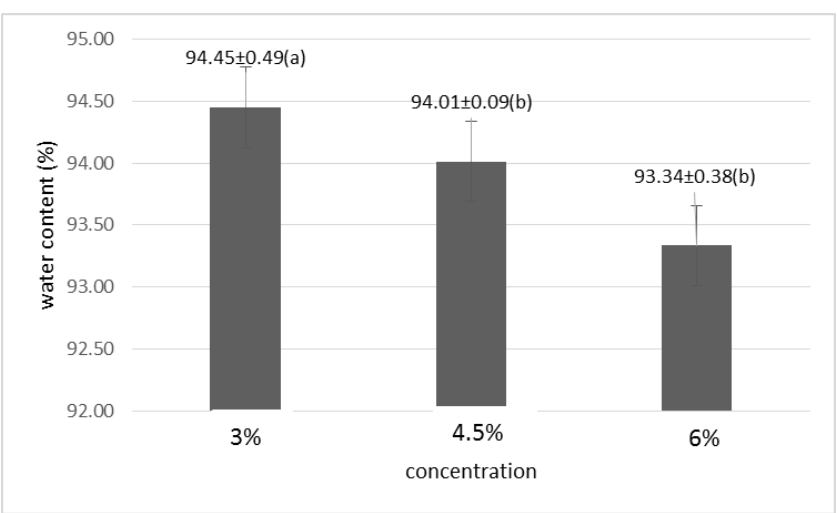

Figure 6. The Result of Water Content

The result of water content at 3\% albumin extract concentration was $94.45 \%$, at $4.5 \%$ concentration was $94.01 \%$, and $6 \%$ concentration was $93.34 \%$. The highest value of water content at a concentration of $3 \%$ was $94.45 \%$ while the lowest water content at a concentration of $6 \%$ was equal to $93.34 \%$. The value of water content decreases with increasing concentration of albumin extract

This publication is licensed under Creative Commons Attribution CC BY. 
given in the making of albumin gel. That is because the higher the concentration of albumin extract, the higher the value of important chemical compositions in the albumin gel

\subsection{Organoleptic}

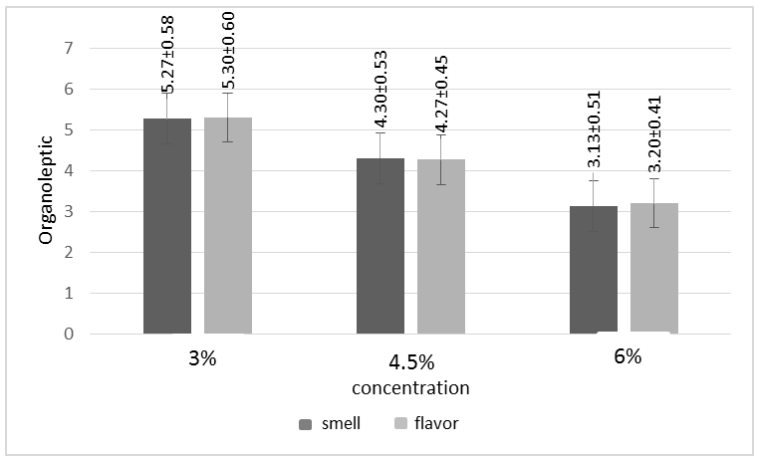

Figure 7. The result of Organoleptic

Organoleptic assessment of albumin gel with different concentrations shows differences. In the treatment of $3 \%$ albumin extract concentration the color parameter showed a value of 5.30, at a concentration of $4.5 \%$ was 4.27 , and at a concentration of $6 \%$ showing a value of 3.20. While the treatment of different albumin extract concentrations on the aroma parameters showed different values. Aroma value of concentration of $3 \%$ was 5.27 , concentration of $4.5 \%$ was 4.30 , and at concentration of $6 \%$ it showed a value of 3.13. color and aroma parameters obtained the highest value of each at a concentration of $3 \%$, while the concentration that has the lowest value is the $6 \%$ albumin extract concentration. The highest values of color and aroma parameters at a concentration of $3 \%$ were 5.30 and 5.27, respectively. The highest value here indicates the panelists liked the color and aroma of the albumin gel produced from the concentration of cork fish albumin extract $3 \%$. While the lowest values of color and aroma parameters at a concentration of $6 \%$ were 3.20 and 3.13, respectively. The lowest value obtained indicates that panelists dislike the color and aroma of albumin gel produced from a concentration of $6 \%$.

\subsection{Animal Testing}

After knowing the optimal concentration of albumin extract for the production of best quality albumin gel is $6 \%$ concentration which is then tested on animals to determine the effect of albumin gel on wound closure, further testing is the analysis of the amino acid profile of albumin gel, and zinc content test. The best concentration of albumin gel is $6 \%$ concentration then compared with negative control and positive control. Mice were injured with a wound length of $2 \mathrm{~cm}$. The process of wound closure was measured for 7 days with observation on the 3 rd day of the 5 th day and 7 th day.

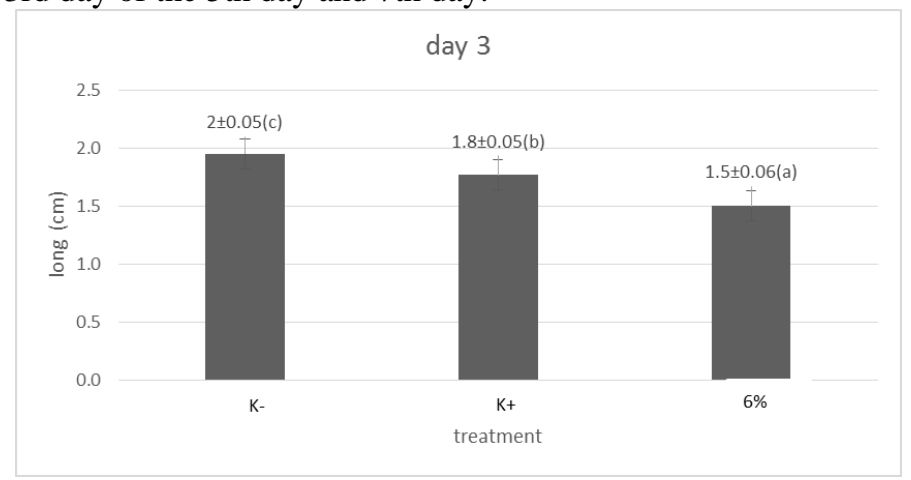

Figure 8. The Result of Day 3

On the 3rd day different treatments showed different results of wound closure. The negative control treatment showed an average wound length of $2 \mathrm{~cm}$, a positive control treatment of $1.8 \mathrm{~cm}$, and a $6 \%$ albumin gel treatment of $1.5 \mathrm{~cm}$. The best wound closure on day 3 was obtained by an albumin gel treatment of $6 \%$ concentration with $1.5 \mathrm{~cm}$ remaining, while the longest wound closure was negative control treatment of $2 \mathrm{~cm}$. This can be interpreted that the wound closure process at the best treatment on the $3 \mathrm{rd}$ day was $25 \%$. 


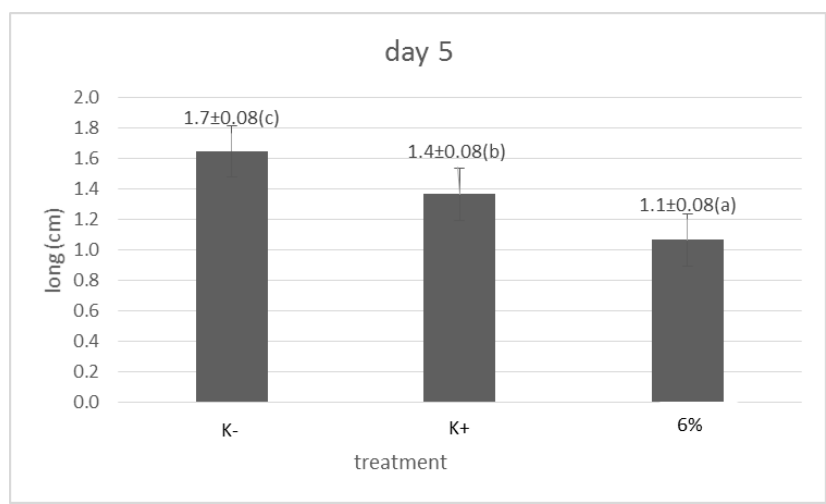

Figure 9. The Result of Day 5

Different treatments show different results of wound closure on the 5th day. The negative control treatment showed an average wound length of $1.7 \mathrm{~cm}$, a positive control treatment of $1.4 \mathrm{~cm}$, and a $6 \%$ albumin concentration gel treatment of $1.1 \mathrm{~cm}$. The best wound closure on day 5 was obtained by a $6 \%$ albumin gel concentration of $1.1 \mathrm{~cm}$, while the longest wound closure was a negative control treatment of $1.7 \mathrm{~cm}$. This can be interpreted that the process of wound closure at the best treatment on the 5th day was $45 \%$.

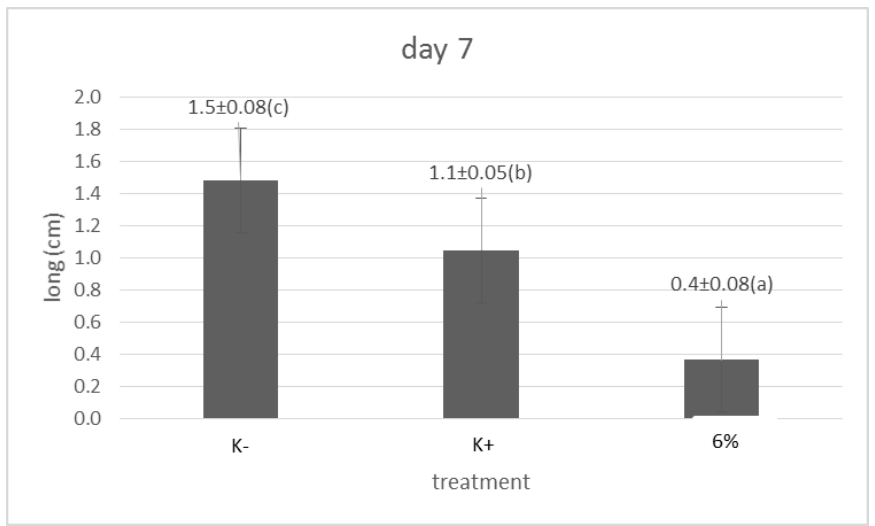

Figure 10. The Result of Day 7

Perawatan yang berbeda menunjukkan hasil penutupan luka yang berbeda pada hari ke-7. Perawatan kontrol negatif menunjukkan panjang luka rata-rata $1,5 \mathrm{~cm}$, perawatan kontrol positif $1,1 \mathrm{~cm}$, dan perawatan albumin gel $6 \% 0,4 \mathrm{~cm}$. Penutupan luka tercepat pada hari ke 7 diperoleh dengan perawatan albumin gel konsentrasi $6 \% 0,4 \mathrm{~cm}$, sedangkan penutupan luka terpanjang adalah pada perawatan kontrol negatif $1,5 \mathrm{~cm}$. Ini dapat diartikan bahwa proses penutupan luka pada perawatan terbaik pada hari ke 7 adalah $80 \%$.

\subsection{Amino Acid Profile}

\begin{tabular}{clcl}
\hline No & Parameter & Unit & Result \\
\hline 1 & L-Glutamic acid & $\mathrm{mg} / \mathrm{kg}$ & 1680.77 \\
2 & L-Phenylalanine & $\mathrm{mg} / \mathrm{kg}$ & 1366.03 \\
3 & L-Isoleucine & $\mathrm{mg} / \mathrm{kg}$ & 619.20 \\
4 & L-Valin & $\mathrm{mg} / \mathrm{kg}$ & 549.07 \\
5 & L-Serin & $\mathrm{mg} / \mathrm{kg}$ & 853.52 \\
6 & L-Alanin & $\mathrm{mg} / \mathrm{kg}$ & 1510.06 \\
7 & L-Arginine & $\mathrm{mg} / \mathrm{kg}$ & 362.60 \\
8 & Glycine & $\mathrm{mg} / \mathrm{kg}$ & 947.88 \\
9 & L-Lysine & $\mathrm{mg} / \mathrm{kg}$ & 1798.09 \\
10 & L-Aspartic Acid & $\mathrm{mg} / \mathrm{kg}$ & 2582.45 \\
11 & L-Leucine & $\mathrm{mg} / \mathrm{kg}$ & 1202.99 \\
12 & L-Tyrosine & $\mathrm{mg} / \mathrm{kg}$ & 44.94 \\
13 & L-Prolin & $\mathrm{mg} / \mathrm{kg}$ & 247.68 \\
14 & L-Threonin & $\mathrm{mg} / \mathrm{kg}$ & 708.42 \\
15 & L-Histidine & $\mathrm{mg} / \mathrm{kg}$ & 810.00 \\
\hline
\end{tabular}

The highest essential amino acid content in cork fish albumin extract was L-Lysine at $1798.09 \mathrm{mg} / \mathrm{kg}$ and the lowest was LArginine at $362.60 \mathrm{mg} / \mathrm{kg}$. While the highest non-essential amino acid content was L-aspartic acid of $2582.45 \mathrm{mg} / \mathrm{kg}$ and the lowest This publication is licensed under Creative Commons Attribution CC BY. 
ISSN 2250-3153

was L-tyrosine of $44.94 \mathrm{mg} / \mathrm{kg}$. Cork fish albumin extract is then used as an active ingredient in gel albumin. The amino acid gel albumin profile is as follows.

\begin{tabular}{clcc}
\hline No & Parameter & Unit & Result \\
\hline 1 & L-Glutamic Acid & $\mathrm{mg} / \mathrm{kg}$ & 441.45 \\
2 & L-Phenylalanine & $\mathrm{mg} / \mathrm{kg}$ & 226.24 \\
3 & L-Valin & $\mathrm{mg} / \mathrm{kg}$ & 155.64 \\
4 & L-Serin & $\mathrm{mg} / \mathrm{kg}$ & 830.17 \\
5 & L-Alanin & $\mathrm{mg} / \mathrm{kg}$ & 404.49 \\
6 & Glycine & $\mathrm{mg} / \mathrm{kg}$ & 459.14 \\
7 & L-Lysine & $\mathrm{mg} / \mathrm{kg}$ & 362.34 \\
8 & L-Aspartic Acid & $\mathrm{mg} / \mathrm{kg}$ & 399.37 \\
9 & L-Leucine & $\mathrm{mg} / \mathrm{kg}$ & 225.81 \\
10 & L-Tyrosine & $\mathrm{mg} / \mathrm{kg}$ & 329.46 \\
11 & L-Prolin & $\mathrm{mg} / \mathrm{kg}$ & 214.80 \\
12 & L-Threonin & $\mathrm{mg} / \mathrm{kg}$ & 239.36 \\
\hline
\end{tabular}

The highest essential amino acid content in albumin gel is L-Lysine of $362.34 \mathrm{mg} / \mathrm{kg}$ and the lowest is L-Valine of $155.64 \mathrm{mg} / \mathrm{kg}$. While the highest non-essential amino acid content was obtained L-Serin of $830.17 \mathrm{mg} / \mathrm{kg}$ and the lowest was L-Proline of 214.80 $\mathrm{mg} / \mathrm{kg}$.

\subsection{Zinc Content}

The best concentration of $\mathrm{Zn}$ in albumin gel was $3.95 \mathrm{mg} / 100 \mathrm{~g}$. The content of $\mathrm{Zn}$ enhances and accelerates the wound healing process. This can happen because $\mathrm{Zn}$ plays an important role in protein synthesis and in cell multiplication. Albumin and $\mathrm{Zn}$ together play an important role in wound healing because albumin has the ability to bind $\mathrm{Zn}$ and transport it in blood plasma.

\section{CONCLUSION}

Cork fish albumin concentration of $6 \%$ is the optimal concentration to produce the best albumin gel. include a pH value of 7 , a viscosity value of $3594 \mathrm{cP}$, an albumin content of 2.00 , a protein content of 3.18 , a fat content of 2.72 , and a moisture content of 93.31 .

The results showed that giving different treatments to wounds had a significant influence on the process of wound closure. At the observations of the 3rd day, 5th day, and 7th day, the process of wound closure was $80 \%$ as good as the experimental animals treated with gel albumin on the 7 th day.

\section{REFERENCES}

Firlianty dan S. B. Pratasik. 2018. Potensi puding ikan toman Channa micropeltes) dan ikan gabus (Channa striata) untuk percepatan penyembuhan pada hewan uji tikus. Jurnal Agribisnis Perikanan. 11(2):65-69. ISSN: 1979-6072

Firlianty, E. Suprayitno, H. Nursyam, Hardoko dan A. Mustafa. 2013. Chemical composition and amino acid profile of Channidae collected from Central Kalimantan Indonesia. International Journal of Science and Technology. 2(4):25-29. ISSN:2252-5297

Husnani dan M. F. Al-Muahzam. 2017. Optimasi parameter fisik viskositas, daya sebar dan daya lekat pada basis natrium cme dan carbopol 940 pada gel madu dengan metode simplex lattice design. Jurnal Ilmu Farmasi dan Farmasi Klinik 14(1):11-18. ISSN: $2716-3814$

Nicodemus, M. Andrie dan S. Luliana. 2014. Uji efek penyembuhan luka sayat ekstrak ikan toman (Channa micropeltes) secara oral pada tikus putih jantan wistar. Jurnal Mahasiswa farmasi Fakultas Kedokteran UNTAN. 1(1):1-14. ISSN: 2551-9713

Siregar, G.R.M. and E. Suprayitno. 2019. Amino acid composition of gelatin from Ephinephelus sp. IOSR Journal of Agriculture and veterinary Science. 12(4): 51-54. ISSN:2319-2372

Tungadi, R., W. Susanty, P. Wicita dan E. Pido. 2018. Transdermal delivery of snakehead fish (Ophiocephalus striatus) nanoemulgel containing hydrophobic powder for burn wound. Pharmaceutical Sciences. 313-323. ISSN: 2383-2886

Vashist, S., S. K. Batra and S. Sardana. Formulation and evaluation of proniosomal gel of diclofenac sodium by using 32 factorial design. International Journal of Biopharmaceutics. 6(1): 48-54. ISSN: 0976 - 1047

This publication is licensed under Creative Commons Attribution CC BY.

http://dx.doi.org/10.29322/IJSRP.10.07.2020.p10360

WWW.ijsrp.org 
International Journal of Scientific and Research Publications, Volume 10, Issue 7, July 2020 